\title{
STRENGTHS AND WEAKNESSES OF THE CHURCH MEDIA IN SLOVAKIA
}

\section{SNAGE I SLABOSTI CRKVENIH MEDIJA U SLOVAČKOJ}

\author{
Terézia Rončáková \\ Faculty of Philosophy, Catholic University in Ružomberok, Slovakia \\ Filozofski fakultet, Katoličko sveučilište, Ružomberok, Slovačka
}

\section{Abstract}

The author analyses strong and weak points of the Church media in Slovakia. Her conclusions are based on more than ten previous researches in the field of Church and media, realized on the Catholic University in Ruzomberok, Slovakia. She states, that Slovak church media are exclusively pastoral, wilfully resigning to the evangelization function. Marginal evangelization attempts (such as in Radio Lumen in the late 1990s) have failed. This means, inter alia, that they do not do journalism in its original sense. They act as public relations bodies of the bishop's conferences and as an extension of spiritual service of the church to the believers. The competent decision-makers (i.e. church hierarchy) are not willing to subsidize evangelization medium, because the currently accepted doctrine is to use 'their own' media space to spread 'their own' messages. Thus, opening complex topics, covering opinion plurality and encouraging discussion, is regarded as harmful. This function is, in the last years, substituted by the commercial project of the Conservative daily Postoj, but this is neither a church nor religious medium. As the researches show, also the request of believing audience for independent critical Church medium is disputable. The audience is disregarding age - divided between the audience of the official church media and decent secular media. Between these two groups exists a relatively strong antagonism.

\section{Sažetak}

Autorica analizira jake i slabe točke crkvenih medija u Slovačkoj. Njezini zaključci temelje se na više od deset dosadašnjih istraživanja na području Crkve i medija, realiziranih na Katoličkom sveučilištu u Ruzomberoku, Slovačka. Tvrdi da su slovački crkveni mediji isključivo pastoralni, namjerno se povlačeći u funkciju evangelizacije. Marginalni pokušaji evangelizacije (kao u Radio Lumnu krajem 1990-ih) nisu uspjeli. To, između ostalog, znači da se ne bave novinarstvom $u$ svom izvornom smislu. Oni djeluju kao tijela za odnose s javnošću biskupskih konferencija i kao produžetak duhovne službe crkve vjernicima. Nadležni donositelji odluka (tj. Crkvena hijerarhija) nisu voljni subvencionirati medij evangelizacije, jer je trenutno prihvaćena doktrina koristiti "vlastiti“ medijski prostor za širenje vlastitih poruka. Stoga se otvaranje složenih tema, koje pokrivaju pluralnost mišljenja i poticanje rasprave, smatra štetnim. Ova je funkcija posljednjih godina zamijenjena komercijalnim projektom Konzervativnog dnevnika Postoj, ali to nije ni crkveni ni vjerski medij. Kao što pokazuju istraživanja, sporni su i zahtjevi vjerovanja publike za neovisni kritički medij u Crkvi. Publika je - bez obzira na dob - podijeljena između publike službenih crkvenih medija i pristojnih sekularnih medija. Između ove dvije skupine postoji relativno snažan antagonizam.

The church media represent a unique segment of the means of mass communication. Several 
studies on the subject concluded that church media have a specific understanding of their role in the society and the definition of journalism per se. Previous researches into the subject include the likes of D. Arasa /1/ which focuses on the use of new media within the church environment; D. Contreras /2/ provides a more general account of church media focusing on their attitude on journalism; N. González Gaitano /3/ focuses on the key question of media evangelization, namely their potential to serve the fundamental goal of communicating the key message of the Church, i.e. to communicate God and salvation; R. Dluhý /4/ discusses the same with a special focus on television; I. Gazda /5/, /6/, /7/ discusses the relation between the Church and new media as well as the operation of specific Vatican media. Within the Slovak environment, systematic scholarly research on the subject is conducted by the Department of Journalism at the Philosophical Faculty of the Catholic University in Ružomberok. I. Gazda /8/ discusses yet unexplored areas of the Christian media market; D. Jacečková /9/ provides an account of the mindset of the members of editorial boards of the church media; T. Rončáková /10/, /11/, /12/ provides a detailed analysis of the church media in terms of stylistics and genres, as well as their internal drivers and bases of argumentation. Within the specific context of religion, the perception of specific media forms by specific audiences has been subject to several works such as that of Hužovičová and Rončáková /13/ which explored the perceptions of the Katolicke noviny (Catholic weekly newspaper) within families or Lysý's /14/ study of older listeners of Rádio Lumen and their attitudes to the broadcasts. The relationship of viewers to the Catholic television channel EWTN in the American cultural environment has also been examined by Dluhý /15/. Special focus has also been placed on strategic and pastoral challenges posed by the shifts in perceptions of media audiences. One of the most comprehensive researches on this topic was conducted by $\mathrm{D}$. T. Maier, N. B. O'Neil and J. M. Harden Fritz /16/. The previous works of the author have analyzed the coverage of presidential elections by Slovak Church media /17/; the attitudes of readers of Katolícke noviny towards the publication's editorial approach to general social and political affairs /18/; inherent features of media communication channel and media language code relative to religious messages in the media /19/, /20/; marketing in Catholic media /21/ and the relationship of young Slovak Catholic to the media /22/. These five sources represent the knowledge base for the analytical part of this paper. In terms of methodology, different approaches were used for different areas of our research: focus groups, Delphi method, indepth interviews, questionnaires, content analysis. The aforementioned studies jointly conclude that the Church attempts to be perceived as being 'in', i.e. to be perceived as being able to keep up with the society and confront it with its message. One of the roles of the church media is to provide pastoral care for believers, i.e. to act as certain internal channel of communication. This aspect of the church media prevails in the Slovak environment. Believers expect the church media to provide them with spiritual service as well as guidance and support in navigating the current social and political questions $/ \mathbf{2 3} /$.

\section{Results}

Our previous researches mentioned in the Introduction may serve as a basis for determining the key strengths and weaknesses of Slovak church media as well as enumerating the challenges they are facing today. The below is a reflection of the activities of the media subject to the previous researches and although the focus is on the most significant and popular ones, these findings can be applied across the board.

A synthesis will be presented in four parts:

1. Target audience and format (church media awareness of their own audience and implications thereof);

2. Need for diversification (mainly due to absence of a leading-edge and respected medium covering broader social and political topics);

3. Journalistic characteristics (conflicting relation to classical journalism especially in terms of language, style, economic considerations, operational processes, human resources management, etc.); 
4. Church influence (attitude of the Slovak church to their media and implications thereof).

\section{Target audience and format}

Generally speaking, Slovak church media typically have unfocused strategies, i.e. they are attempting to target all audiences. They usually position themselves as 'family-oriented media' with content appropriate for members of all generations. Thus, they are investing in children or youth sections/shows, covering current affairs and politics, and placing emphasis on spiritual and other content appealing to more senior recipients. Nevertheless, surveys confirm that the current audience of Radio Lumen can be generally described as 'aged house-wives' /24/ - a finding which concords with C. T. Maier, N. B. O'Neil or J. M. Harden Fritz /25/, who also observed majority of female audience of church media which often find difficult to target younger audiences. The above feedback from external environment points to a deeply embedded prejudice: church audiences are regarded economically inactive and of poor purchasing power. This was also confirmed by our previous research on marketing techniques employed by church media /26/ ${ }^{1}$ where chief editors of Katolicke noviny and Radio Lumen concluded that they are not viewed as interesting partners for advertisers trying to target more wealthy audience.

It should be noted that the church media management's awareness of their own audiences are rather vague and mostly based on feelings. Church media in Slovakia do not invest in professional surveys and do not examine their audience, and even fail to define specifically their target audiences which would be the driving factor for the content they offer. Thus,

\footnotetext{
${ }^{1}$ The research focused on the three most important Slovak Catholic media: Katolicke noviny weekly, Radio Lumen and TV Lux. These media draw attention of a great part of audience, including the church hierarchy, to which all three of them are - although under different arrangements - de jure or de facto subordinated. Data and information was obtained from qualitative structured interviews with competent professionals working in individual media and our own observations from inside these institutions. The interviews can be divided into official and unofficial. The latter were conducted mainly in $T V L u x$, where persons officially in charge refused to provide the requested information.
}

their decisions are usually made on their own information gathered among their own recipients. However, this kind of approach fails to provide an objective picture of the reality (mostly due to unrepresentative sample of people willing to provide feedback, not to speak about the fact that opinions are usually gathered only from existing recipients and not from potential ones). An exception to the aforementioned approach was Radio Lumen under the leadership of Vladimír Slovák (1995 - 2003) which invested into professionally-led focus groups so as to fine-tune their radio schedule. This has attracted new type of audience even from the younger generations including non-believers and has led to higher listenership rates. However, the effort was stopped by an opinion discord with the Slovak Bishops' Conference and subsequent suspension of V. Slovák from the office (he was relocated to a small remote parish).

Thus, as mentioned above, the awareness of Slovak church media editorial boards of their own audiences remains vague which translates into their strategies. As part of our previous research on the transmission of religious messages through media communication channel /27/2 František Múčka, one of the more experienced Slovak journalists, called this strategy a 'weird mixture'. Or consider Petr Kolář, a Czech Jesuit with extensive media experience, who used the term 'one-room school' /28/. In this case, mismanagement of church media was compared to an old-type schools where students from several grades were only assigned one teacher who had to switch between individual subjects during the lessons. Such an approach makes it difficult to set targets, select any reasonable means of their accomplishment or measure efficiency.

In addition, what usually happens in mixed groups is that weaker members slow down the more progressive ones. In the case of church media, this translates into a lack of trust of the

\footnotetext{
2 The research was performed by the method of focus groups and qualitative content analysis; this text refers to the conclusions obtained through interviews. As many as ten focus groups were conducted, using two methods - as part of phase one, we conducted seven focus groups with professionals using the Delphi method and in phase two, these were three focus groups with lay audience.
} 
editorial boards to their own recipients: they are afraid to have them cover challenging topic because they do not trust they have the ability to critically process such content. The board members usually base their approach on a vague notion that a part of the audience perceives the entire content "as if it were Holy Scripture". Therefore they cannot afford to "confuse people", as articulated by Jozef Kováčik, then-spokesperson of the Slovak Bishop's Conference. According to these officials, the interpretation of church and social affairs by the church media must be straight-forward, controversial topics require a clear conclusion on "what is right" and thus, different opinions are undesired content.

\section{Diversification of church media}

The above considerations point to a pressing need to diversify the church media in Slovakia so as to provide room for more specialized print or radio products (while putting aside television as too costly). The absence of a family-type social and political medium was identified long time ago (cf. Gavenda, /29/). Critical reviews of social and political developments were attempted by Zrno weekly which had an extensive samizdat tradition. This attempt failed due to its provocative and highly opinionated content and loss of 'imprimatur' (license provided to print media by church officials to have the privilege to be distributed in churches). Another attempt to establish a modern Christian monthly was Família (also with quite a respectable samizdat publishing history). It appears that these projects face severe challenges mostly related to the small size of Slovak market and other practical problems, especially when set up as private businesses since the Slovak church hierarchy does not feel the need for their existence - on the contrary, the officials are content with current status quo. According to J. Kováčik there is an ongoing significant shift from print to electronic media, where the church sees a huge progress. For Kováčik, the model of 'web-pages Radio Lumen - Katolícke noviny - TV Lux' all works fine - despite some imperfections of some of its subcomponents (cf. Kováčik, /30/).

Thus, a regularly recurring dispute on the role of church media is a typical phenomenon with- in the Slovak church media discourse. Should the church media provide inspirational opinions on social and political and church/political developments? Should they be open to controversial topics? Should they publish opinions from both (or several) opinion camps? Should they be providing argumentation bases in the most hotly debated stories? These were the kinds of questions discussed at four conferences named 'Do the Catholic Media Fulfil Their Role?'. ${ }^{3}$ Current general consensus is that church media are too restrained to challenge their media audience in that respect. For instance, Christian politicians in Slovakia have often pointed to the fact that church media were unable to support their religiouslymotivated causes (such as anti-abortion laws or work-free Sunday) and they felt rather abandoned on the barricades.

The social and political engagement of church media in Slovakia was subject to two more detailed studies related to presidential election in 2014. The analysis of Slovak Catholic and Protestant nationwide media $/ \mathbf{3 1} /{ }^{4}$ pointed to a significantly constrained approach to covering the election. As concluded by the study, "compared to the satiated public discussion and media space by the presidential election campaign, the examined media showed relatively little engagement in covering such a crucial social and political event" /32/.

With respect to covering the elections, the church media refrained from presenting their own positions. In fact, they typically tried to provide either even coverage to all candidates (Katolícke noviny) or no coverage to any candidate (Televizia Lux, Evanjelický posol spod Tatier). Interviews with candidates were characteristi-

\footnotetext{
${ }^{3}$ Held in 2005, 2009, 2011 and 2014. Along with Catholic University in Ružomberok, they were organised by voluntary associations Forum for Public Questions and Network Slovakia, which initiated the project. Thus, it was an initiative of engaged Catholic lay persons who found the condition of the church media in Slovakia unsatisfactory.

${ }^{4}$ In this research we used the content analysis method (mostly qualitative) on a sample of all official nation-wide church media, with sufficient coverage and at least partial socialpolitical focus. Thus, we arrived at five media: Katolicke noviny, TV Lux, Radio Lumen, Evanjelický posol spod Tatier weekly and Evanjelický východ monthly. The first three were Catholic, the rest Lutheran. In total, 18 texts were examined.
} 
cally free of any signs of disagreement- no candidates were confronted by the journalists, easy-going guest speakers or respondents were selected. Similarly, a survey conducted by Katolícke noviny approached all candidates, but only to allow them to present themselves in positive light.

These findings have led us to a question of the demands the audiences place on their church media: Are they interested in greater engagement of their media in social and political causes and clarification of positions on political issues? As shown in our survey among engaged readers of Katolícke noviny $/ 33 / 5$, almost $40 \%$ of respondents are not satisfied with the editorial boards' approach to election coverage; and further $40 \%$ were neutral on this question. Dissatisfied respondents often concluded that the editorial boards were 'feared'; that the coverage was 'dull' or that they lost their 'salinity'.

The respondents' opinions on the question of whether church media should clearly endorse specific candidate or candidates in any type of election have proved to be quite balanced: both camps are of similar size, but a 'definite yes' or 'definite no' were presented by a quarter of respondents for each camp, while $11 \%$ was neutral.

In terms of genres, respondents seek commentaries of well-known public figures (beyond the editorial board or church hierarchy) and analyses of candidates and their programs. Both were demanded by more than a half of the respondents.

As clear from the above, there are calls for more engagement and critical thought but only by a part of the audience. Thanks to our research we can draw more precise conclusions of this group's characteristics. In the aforementioned survey among the Katolícke noviny readers, a significant divide could be observed between individual groups depending on gender, age or education. In general, male readers

\footnotetext{
${ }^{5}$ This question was addressed through a questionnaire in the electronic form distributed by several methods. The questionnaire included 26 questions related to readers' activities, their election behaviour and attitudes on the social and political coverage presented by Katolícke noviny.
}

were more dissatisfied with the periodical's approach to elections coverage (56\% were dissatisfied). Female readers were usually neutral or satisfied. Male respondents were more inclined to ask for clarity on the periodical's endorsement of specific candidates and significantly more often called for opinionated genres and interviews with selected candidates. The positions of male readers were mirrored by younger respondents aged less than 30 (more than 63\% dissatisfied) and university educated respondents.

Similar to our findings in media reception of young engaged Catholics $/ 34 / 6$ more female than male recipients found the religious media (Katolícke noviny, Radio Lumen, TV Lux, Vatican Radio, TV Noe) to be inspiring. Among male recipients, a greater preference for decent secular media and foreign media was noted.

In this research, antagonistic attitudes between religious audiences and decent secular media audiences were observed. Using the ANOVA test we identified three basic groups of audiences: religious, decent and tabloid/television. Respondents from 'religious' group showed above-average favour toward the church media and above-average aversion toward decent secular media; within the 'decent' media group, this was exactly opposite.

The above observations were supported by opinions of individual audiences on the current church developments and general current affairs (coverage of specific stories was examined, specifically the removal of Archbishop

\footnotetext{
${ }^{6}$ The data used in this study was collected using the quantitative and quantitative method of questionnaire survey. The questionnaires consisted of 27 questions. Two questions covered the respondents' relation to the media: one half-open question asked respondents which media outlets they are regarding as being influential or inspiring, and a closed question asked respondents to evaluate their awareness of various media outlets on a scale from 1 to 10 . For the purposes of the study, the group of respondents was restricted to young (aged from 18 to 40) engaged Catholics who identified themselves as such; indeed, this was the key condition for participating in the research. The chosen participants had also declared various specific forms of social or religious engagement which were addressed by targeted research questions. The questionnaire was published online and was disseminated in cooperation with 20 institutions, whose memberships were likely to contain suitable participants for the study. We obtained 339 relevant responses, $51 \%$ male and $49 \%$ female.
} 
Róbert Bezák,7 separation of church and state and celibacy). A clear divide between the recipients of official church media and all the rest could be observed. The church audience maintained above-average trust toward the authority of Rome in the case of removal of the Archbishop Bezák (an average of 19\% compared to the overall average of $14 \%$ ), a belowaverage perception of injustice in his removal (an average of $38 \%$ church media respondents compared to the overall average of $44 \%$ ); above-average ignorance of the problem of separation of state and church (an average of $23 \%$ compared to total average of $18 \%$ ), as well as more definite rejection of the separation of the church from state $(24 \%$ of respondents saying 'definitely not' compared to the overall average of $17 \%$ ); above-average praise of celibacy as reasonable (an average of $70 \%$ compared to the overall average of $61 \%$ ) and below-average number of respondents calling for making celibacy optional (an average of $27 \%$ compared to the overall average of 33\%). Exactly opposite trends were observed for all the remaining media.

\section{Is this journalism?}

Our previous researches into the church media (cited above) suggest that the output of church media cannot be regarded as proper journal-

\footnotetext{
7 The removal of Archbishop Róbert Bezák sparked massive and continuous attention of Slovak media and public. Born in 1960, Róbert Bezák is a preacher of the Redemptorist order with a reputation of a popular charismatic missionary. He has led the office of the provincial for 12 years. In 2009, the year he was appointed Archbishop of the Trnava Archdiocese, and Bezák was generally regarded as a reformer, since at the time of his appointment, the diocese faced accusations of fraud and mismanagement of funds. Prior to his appointment, media had drawn a negative image of the personality of the Archbishop Emeritus Ján Sokol, who had been generally viewed as complacent, greedy and self-indulgent person. Media had often emphasized Sokol's controversial opinions on fascism in Slovakia during the $2^{\text {nd }}$ World War. In July 2013, Archbishop Bezák was removed from office by Benedict XVI. The church refused to disclose the reasons for his removal. Thereafter several internal church documents leaked to media, Archbishop gave several interviews, and finally, the Vatican expressly banned former Archbishop to communicate with the media. He spent 2014 at a retreat centre for emeritus Redemptorist priests at Bussolengo, Italy. He currently lives in Slovakia with his sister and parents. Despite his personal audience with Pope Francis, he publicly declared the lack of hope for a solution of his case and the need for him to live a civic life.
}

ism. Their aims and instruments are legitimate and justifiable, and clearly, there is significant demand for their product, but one cannot speak about journalism. Journalism is a form of public service for citizens, provides them with information, helps them shape their opinions so that they become better citizens (cf. research interview with N. González Gaitano, /35/). In that respect, D. Contreras speaks about the so-called 'devotional media' (pointing specifically toward the Italian Catholic television Telepace), which, in his view, are not media as they do not do journalism (cf. research interview with D. Contreras, /36/). The participants to our research on the transmission of religious messages through media reflected upon this question as loss of journalistic attractiveness and informational value of church media content. "They only wish to be pleasant and soothing, to become sort-of 'chicken-broth for soul'," as articulated by one of the respondents. As a result, rhetorical, essay, educational or even administrative style prevails over journalistic style. Complex topics are neglected rather than covered and general lifestyle trend is followed by church media editors appealing to simple and low needs of their audiences.

The impact of the phenomenon described above on genres was documented in the above cited research on the behaviour of church media during the election campaign. For instance, Katolicke noviny published two reflections under the caption 'commentary', which, however, did not meet the standards of commentary genre. The reflections they wrote were general, used non-expressive language, without stating any clearly defined position. An opinion survey seems to be a favourite genre of church media content before any election. However, this is a shortcut - if not an inversion - of the role of a journalist, which is to inform, set direction. An opinion survey creates room for self-presentation for the candidate and deprives the editorial board/author of the opportunity to intervene into the debate, confront the candidate with challenging questions, insist on a clear answer, or challenge a misleading or manipulating comment.

Quite often, journalists working for secular media do not regard their church media col- 
leagues as true journalists. As concluded by a long-time journalist F. Múčka, "they do not have relevant journalist experience" /37/. According to Múčka, a person cannot boast with the title journalist, if he or she does not engage in any investigative work, does not suffer the toil of 'digging out' the information he or she needs, does not - from time to time - receive any threat from someone in power, and, on top of that, is unprofessionally convinced that he or she is part of a constant battle against the adversary outside world.

Based on our research, it was concluded that church media in general follow the 'path of lesser resistance' and they are happy with employees without high journalistic ambitions, who, to put it bluntly, do not cause unnecessary trouble. As concluded by one of our respondents, "There is no room for a professional and ambitious journalist in the church media."

The 'anti-journalistic' nature of church media can also be inferred from a strange, selfimposed, voluntary and clearly misunderstood 'public service nature' of church media, which could be observed during the period of presidential election campaign. In that respect, some media (Katolicke noviny, TV Lux) were afraid to provide disproportionate room to all candidates. However, these fears are antijournalistic per se and other media clearly do not share such fears.

The above considerations are also related to a deliberately non-commercial focus of the church media. Management and owners regard such focus an advantage. As part of our research on the transmission of religious messages, J. Kováčik presented an opinion that only the non-profit media are 'true' media, because unlike the 'commercial' and 'public service' media, they do not seek profit beyond their investment needs, and are not bound by the chains of profit. In practice, this approach is translated into higher demands on motivational factors other than financial factors within the church media. This 'other' form of motivation is supposed to lead church media employees to produce quality comparable to commercial competitors. However, our previous researches led to two key conclusions:
Firstly, the demands of employers on the internal spiritual motivation of employees are usually exaggerated and, as a result, hardworking employees feel unappreciated. Secondly, proper use of non-financial motivation not only requires personal maturity but also other external factors and limitations come into play which make it difficult to pursue this ideal - unlike easy-to-use and efficient financial motivation which definitely has its place in the theory of motivation (cf. Repková, /38/).

\section{Influence of the Church}

Finally, last of the factors we will dwell upon and which determines the nature and quality of the church media in Slovakia is external influence of the church. According to public relations experts, the Catholic Church has been the 'cornerstone' of strategic communication or so-called PR, especially in the light of the foundation of a special instrument for effective evangelization, Sacra Congregation de Propaganda Fide, in 1622 /39/. Pressures of the Church are often translated into a set of generally accepted rules applied mostly to the selection of topics and nature of the coverage, including the selection of sources and guest speakers for discussions. As suggested by our research on the transmission of religious messages, within the Slovak church media one can still observe an 'embargo' on certain people and topics This was confirmed by literally all professional participants of our focus groups with hands-on experience from within the church media. F. Múčka even called it 'supercensorship': "For some reason we keep complaining on secular media that they refuse to provide room for this or that person, priest or believer, but within the church media, a much tougher embargo on certain people is at work". /40/

J. Kováčik justifies the 'embargo' by the need "not to waste time and room for other, opposing opinions" /41/. According to him, the space which the church media managed to conquer within the public arena for religious messages is too precious and thus it should only be used to present the church's own positions. Thus, stringent selection criteria are applied on religious media communicators who, according to J. Kováčik, must have a special 'mandate'. In 
this respect, on 12 March 2013, the Slovak Bishop's Conference published the decree Mass Media Presentation Standards for Clergy and Members of Monastic Orders, according to which each member of the clergy must first seek consent with his or her superior before presenting an opinion in the media. In journalistic and general lay public, this decree was nick-named 'the muzzle act', a term coined by the Czech philosopher and priest, Tomáš Halík /42/.

This sort of 'constant oversight' is embedded in the DNA of Slovak church media. Their internal structure does not resemble the spider-shaped organizational structures within standard businesses with owners or management on the top. In this type of media, church hierarchy either stands on top as the owner, or above the owner. Thus, hierarchical structure of the church is often translated into the way these media are managed. "As a matter of fact, chief editor is under a huge pressure," concluded the Juraj Gradoš, a priest and chief editor of the Greek-Catholic bi-weekly Slovo. Thus, within the church media, we see overlapping relations originating from two different modes of operation - the obligation of obedience of a priest toward his bishop is transposed to the obligation of a chief editor/priest to his superior. According to former head of Radio Lumen, Vladimír Slovák, Slovak church media are not becoming more professional simply because loyalty is ranked above professionalism. According to him, such an approach is both harmful and wrong because it is based on an invalid assumption that "church equals hierarchy". "However, loyalty to the officials of the Slovak Catholic church may not always be the same thing as loyalty to the Catholic Church and her Teaching!" /43/.

In view of the above, the Slovak church media act more as public relation bodies of the Slovak Bishop's Conference than journalistic institutions challenging the outside world with unpleasant questions or performing investigative work. In a sense, they somehow appear to be standing on the other side of a hypothetical barricade - they somehow find themselves on the PR front. The Press Agency of the Slovak Bishop's Conference is a typical example. It is a 'press agency' by name, but does not offer news service or other products derived from current press (or information) agencies, but limits itself to the provision of a PR service to the Slovak Bishop's Conference.

\section{Conclusion}

One of the long-standing questions on the church media continuously raised in professional circles in Slovakia is that of their pastoral vs. evangelization character. Should these media provide a spiritual service to the believers - or are they called to become tools for evangelization? Should they approach nonbelievers or partially identified audiences as well? What is their task and which task are they currently fulfilling? The answer to the last question is clear: Slovak church media are exclusively pastoral. Marginal evangelization attempts (such as in Radio Lumen in the late 1990s) have failed.

In addition and as mentioned previously, the Slovak church media do not do journalism in its original sense. They act as public relations bodies of the bishop's conferences and as an extension of spiritual service of the church to the believers. This approach is reflected in both the composition of their genres (nonjournalistic material) and personal profiles of their employees (non-journalistic backgrounds).

Nevertheless, this is not to say that they are doing a bad job. On the contrary, they provide useful spiritual and informational service which is a legitimate aim of the publisher/media owner to audiences of sufficient size. At the same time, this means that in current Slovak church media market, there are no evangelization media, nor church media which would extend their coverage to general current affairs.

Slovak market appears to be too small for a successfully operating medium of this kind. ${ }^{8}$ At the same time, competent decision-makers (i.e. church hierarchy) are not willing to subsi-

\footnotetext{
8 This is one of the lessons learned by the newly founded Conservative daily Postoj (founded in September 2015), published in the form of web portal and rather laboriously attempting to finance its activities through individual donations. This example is presented only to illustrate the situation because this is neither a church nor religious medium, although religious topics form a stable part of its content.
} 
dize such medium because the currently accepted doctrine is to use 'their own' media space to spread 'their own' messages. Thus, opening complex topics, covering opinion plurality and encouraging discussion is regarded as harmful.

The long-term demand for a more critical church medium can only be seen in a part of Slovak audience - these is mainly younger male audience with higher education. However, one cannot speak of a prevailing trend in the entire society. The research conducted on the population of young engaged Catholics in Slovakia points to an internal divide between the audience of the official church media and decent secular media, and also points to a relatively strong antagonism between the two groups.

Notes

/1/ Arasa, D. (2008): Church Communications Through Diocesan Websites. A Model of Analysis, Edusc, Roma.

/2/ Contreras, D (Ed.) (1998): Chiesa e comunicazione. Metodi, valori, professionalità, Libreria Editrice Vaticana, Roma.

/3/ González Gaitano, N. (2001): Evangelizzare con $i$ mass media?, journal "Studi Cattolici", No. 484, Vol. 46, p. 404-412.

/4/ Dluhý, R. (2013): Media effects of basic Christian message presented on television, journal "Revista română de Jurnalism şi Comunicare", No. 2-3, Vol. 8, p. 69-79.

/5/ Gazda, I. (2010): The Vatican Daily L'Osservatore Romano, journal "Questions on journalism", No. 34, Vol. 53, p. 135-146.

/6/ Gazda, I. (2012b): The Holy See Press Office, journal "Questions on journalism", No. 3-4, Vol. 55, p. 88-94.

/7/ Gazda, I. \& Kulla, A. (2013): The Use of New Media in the Catholic Church, journal "Informatologia", No. 3, Vol. 46, p. 232-239.

18/ Gazda, I. (2012a): Catholic Media in PosCommunist Slovakia, pp. 485-535 in Valčo, M. \& Slivka, D. (eds.) Christian Churches in PostCommunist Slovakia: Current Challenges and Opportunities. Centre for Religion and Society, Roanoke College, Salern.

/9/ Jacečková, D. (2013): Žurnalista v katolíckom médiu na Slovensku [Journalist in Catholic Medium in Slovakia], dissertation thesis, Catholic University, Ružomberok.

/10/ Rončáková, T. (2009a): Prienik náboženského a publicistického štýlu I. Ked' chce cirkev hovorit' mediálnym jazykom [Intersection of Religious and Journalistic Style I. When the Church Speaks Media Language], Philosophical Faculty of the Catholic University, Ružomberok.

/11/ Rončáková, T. (2009b): Prienik náboženského a publicistického štýlu II. Ako cirkev hovorí mediálnym jazykom [Intersection of Religious and Journalistic Style II. How the Church Speaks Media Language], Philosophical Faculty of the Catholic University, Ružomberok.

/12/ Rončáková, T. (2010): Prienik náboženského a publicistického štýlu III. Môže cirkev hovorit' mediálnym jazykom? [Intersection of Religious and Journalistic Style III. Can the Church Speak Media Language, Paulínky, Prague.

/13/ Rončáková, T. \& Hužovičová, T. (2012): Katolícke noviny vo vnimaní čitatel'ov vo viacgeneračných rodinách [Katolícke noviny as Perceived by Readers in Multi-Generational Families], journal "Questions on Journalism", No. 3-4, Vol. 55, p. 29-40.

/14/ Lysý, D. (2014): Publikum slovenského krest'anského rádia. Kvalitatívny výskum publika Rádia Lumen formou skupinových rozhovorov [The Audience of Slovak Christian Radio. Qualitative Research into the Audience of Radio Lumen Based on Focus Groups], dissertation thesis, Catholic University, Ružomberok.

/15/ Dluhý, R. (2014): Kerygma vo vybraných katolíckych televíziách a jej adresáti [Kerygma in Selected Catholic Televisions and Target Audience], dissertation thesis, Catholic University, Ružomberok.

/16/ Maier, C. T. \& O'Neil, N. B. \& Harden Fritz, J. M. (2014): Who Reads Catholic Newspaper? Exploring Readership in a Changing Industry, journal "Journal of Media and Religion", No. 3, Vol. 13, p. 153-169.

/17/ Rončáková, T. (2014b): Spracovanie prezidentských volieb 2014 vcirkevných médiách [Coverage of Presidential Election 2014 by Church Media], pp. 147-166 in Petranová, D. \& Pavlů, D. (eds.) Demokratizačná funkcia médií: ideál a realita [Democratisation Function of Media: The Ideal and the Reality]. Megatrends and media 2014, Faculty of Mass Media Communication of the University of Ss. Cyril and Methodius, Trnava.

/18/ Rončáková, T. (2014a): Prístup Katolíckych novín k politickému dianiu. Postoj a podnety angažovaných čitatel'ov [Approach of Katolícke noviny to Political Affairs. The Attitudes and Suggestions of Engaged Readers], journal "Communication Today", No. 2, Vol. 5, p. 80-95.

/19/ Rončáková, T. (2010), op. cit.

/20/ Rončáková, T. (2013): Can the Church use media communication channels? Inherent features of media communication channels relative to religious messages in the media, journal "Central European 
Journal of Communication", No. 1/10, Vol. 6, p. 67-88.

/21/ Rončáková, T. (2011): Marketing in Catholic Media, pp. 123-146 in Rončáková, T. \& Lysý, D. (eds.) Religious Messages in Media, Edusc, Roma.

/22/ Rončáková, T. (2015): The Relationship of Young Slovak Catholics to the Media, journal "Communication Today", No. 2, Vol 6, p. 62-76.

/23/ Rončáková, T. (2010), op. cit., p. 236-239, 272277.

/24/ Štofaník, V. (2013): Prieskumy počúvanosti slovenských rádii; sept. 2011 - sept. 2012 [Survey of Listernership of Slovak Radios; Sep 2011-Sep 2012], lecture given at the Department of Journalism in Ružomberok.

/25/ Maier, C. T. \& O'Neil, N. B. \& Harden Fritz, J. M. (2014), op. cit.

/26/ Rončáková, T. (2011), op. cit.

/27/ Rončáková, T. (2010), op. cit.

/28/ Ibidem, p. 173.

/29/ Gavenda, M. (2005): Chceme oživit heslo: Katolícke noviny do každej rodiny [Reviving the phrase: Katolícke noviny for Every Family], pp. 9-22 in Dyttert, M. (ed.) Do Christian Media Fulfil Their Task in Slovak Society?, Philosophical Faculty of the Catholic University, Ružomberok.

/30/ Kováčik, J. (2009): Potrebuje Rimskokatolícka cirkev médiá? Katolícke médiá na Slovensku včera a dnes [Does the Roman-Catholic Church Need media? Catholic Media in Slovakia in the Past and Present], lecture given at the 'Media, Ethics and the Role of Christian' Seminar, organized by
Ladislav Hanus Fellowship 13 - 15 March 2009 in Nitra.

/31/ Rončáková, T. (2014b), op. cit.

/32/ Ibidem, p. 151.

/33/ Rončáková, T. (2014a), op. cit.

/34/ Rončáková, T. (2015).

/35/ Rončáková, T. (2010), p. 130.

/36/ Ibidem, p. 78.

/37/ Múčka, F. (2009): Prečo je normálne, že v médiách nemajú radi cirkev, a prečo sú tí, ktorým sa to nepáči, pokrytci [Why is it Normal that Media Don't Like the Church and Why are Those that Don't Like It Hypocrites], lecture given at the 'Media, Ethics and the Role of Christian' Seminar, organized by Ladislav Hanus Fellowship 13 - 15 March 2009 in Nitra.

/38/ Repková, T. (2004): Ako robit’ profesionálne noviny [How to do Professional Newspaper], Open Society Foundation, Bratislava.

/39/ Hejlová, D. (2015): Public Relations, Grada, Prague.

/40/ Múčka, F. (2009), op. cit.

/41/ Kováčik, J. (2009), op. cit.

/42/ Strižinec, M. (2013): Špeciál o Robertovi Bezákovi [ A Special on Robert Bezák], in TA3 (9. 2. 2013), http://www.ta3.com/clanok/1014574/special-orobertovi-bezakovi.html.

/43/ Slovák, V. (2009): Diskusný príspevok [Contribution to Discussion], pp. 79-81 in Kravčák, P. \& Volček, M. (eds.) Do Christian Media Fulfil Their Task in Slovak Society?, Philosophical Faculty of the Catholic University, Ružomberok, p. 81. 